\title{
Assisting the Sustainability of a Well-managed State in Times of Pandemic Crisis
}

\begin{abstract}
Summary
As a consequence of the epidemiological situation a number of unfavorable economic and social effects has emerged already that need to be mitigated. The State Audit Office of Hungary seeks to address this precarious and difficult situation by continuing to ensure the sustainability of a well-managed state when carrying out its activities; nevertheless tackling it from a slightly different approach. The virus claimed a set of new methods, and other activities became more important, such as advisory activities, monitoring audits, which could not have been done without change and crisis management, as well as the relevant digitization tools. The article presents the work and performance of the State Audit Office of Hungary, which aims to improve the harmful economic and social repercussions of the current virus.
\end{abstract}

Journal of Economic Literature (JEL) codes: H10, P43, P48

Keywords: well-managed state, monitoring, consulting, analysis

\section{INTRODUCTION}

The epidemiological situation has caused a number of changes at both social and economic levels. More self-discipline is required than ever before and the population shall adapt to changes in everyday life. The economy is also fraught with excessive uncertainty due to the unexpected expenditures as well as the negative effects of the

LÁszló Doмoкos PhD, President of the State Audit Office of Hungary (elnok@asz.hu). 
Civic Review · Vol. 16, Special Issue, 2020

pandemic it has to deal with in a way that makes it almost impossible to guess when the current economic pressures will ease. These negative effects have already been addressed in several articles, for example by Lentner and Cseh (2020) who have examined state-owned enterprises in the context of a global health care epidemic during which continuous and adequate public services are essential.

Even after the declaration of the state of emergency, the State Audit Office of Hungary performed its tasks set out by law in accordance with the rules of the constitutional state, thus auditing the 2019 final accounts and assisting in the preparation of the 2021 budget by giving its opinion, the compilation of which required more significant performance of tasks this year than ever before due to an ever-changing environment. However, the SAO not only focused on organizations that must be audited in accordance with the law, but also tried to implement its audit, analysis and advisory activity as widely as possible in order to help the work of beneficiary organizations using public funds and public assets as efficiently as possible, and support quality spending, the basic principle of responsible management, transparent operation and enforced financial management, thus strengthening the trust of society in public institutions and other state-owned organizations.

Of course, in the current situation full of challenges, the SAO recognized that it shall provide organizations with its statutory advisory activity and analysis arising from its legislative authorisation, and that a significant part of audits should take place as efficiently as possible, in order to shed lights on the irregularities arising from the financial management and operation of the audited entities, while at the same time sought to reduce the burden on them as much as possible. These changes have also brought about serious methodological changes for the SAO, the significance of digitisation has become even more emphasized, and the advisory role has become more valuable than ever before.

In this article, we intend to show how advisory models are structured and how the SAO is related to them. The SAO's new audit method will also be described, in other words the monitoring-based audit, which focuses on efficiency and prevention. In addition, we present recent tailor-made analyses, given that they are significantly related to the virus epidemic and to everyday life, so they are unquestionably in the spotlight. It should not be forgotten that the SAO, just as well as all organizations have experienced changes in the recent period necessitating tools such as change management and/or crisis management. If we do not take advantage of these, we will not be able to adapt to the current environment causing considerable harm not only to the organisation, but also directly or at least indirectly to society. In direct connection with its activities and role in the economy, one of the privileged roles of the SAO is to participate to a well-managed state contributing to its sustainability. And a well-governed state helps to achieve a high degree of social value added.

MAINTAINING A WELL-MANAGED STATE AND THE COUNSELLING MODELS

Transparency and accountability of public funds have long been a general criterion, but at the same time it raises many difficulties for individual organisations, especially 


\section{László Domokos: Assisting the Sustainability of a Well-managed State in Times...}

the task to create an assurance based documentation (Domokos, 2019). In order to meet this criterion, there are three lines of defence at disposal: the first is the management's internal control system, the second is the control performed by the operator and the owner, and the third is represented by the external, independent audit.

The present article addresses the third line of defence in more depth and with a slightly broader approach. Namely, the task of the third line of defence, in this case the task of the SAO, extends not only to auditing, but also to the performance of duties such as consulting and analysis. These activities are becoming more and more important in the current pandemic, and László Domokos (President of the SAO) declared in the Magyar Nemzet daily newspaper that "we are providing the auditing to the Hungarian National Assembly to identify problems as an audit institution, moreover, our analysis and advice may lead to finding a solution to these issues. In other words, with our cooperation, not only the situation of the individual audited entities can improve, but also the use of public funds shall become more efficient at the level of the national economy" (Jakubász, 2020).

Because consulting plays a significant role in the activities of the SAO, it seems worthwhile reviewing the advisory models and approaches in general. By an advisory model we shall mean the structured, interconnected steps and phases that determine the process of the advisory activity. Different models have been developed for different types of advisory activity (e.g. career counselling, IT and quality consultancy, management consulting activities), but there is a general counselling model that describes a problem-solving, decision-making process that can be applied to all, regardless of the type, problem and goal.

\section{General Counselling Model}

The general advisory model outlines a process that must be followed throughout counselling, regardless of the theoretical framework and any methodology (Ivey and Simek-Downing, 1980).

Figure 1: General Counselling Model

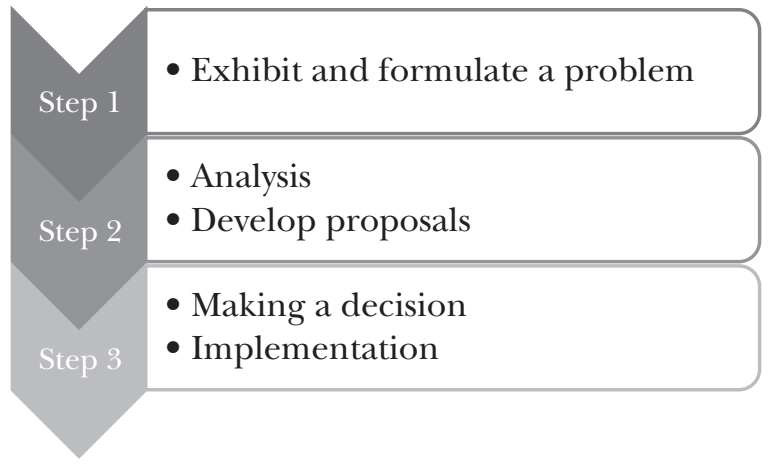


As shown in the figure, the Ivey-Dowing model divides the counselling process into 3 steps. The first step is to explore the problem, during which it becomes unambiguous what the counselling is aimed at, in other words to shed light on the problem. Counselling will therefore focus on this. In the next step, the problem is analysed and recommendations are made to solve it, alternatives are finally decided, solution is brought into focus, and is implemented (Pecze, n. d.).

\section{General model(s) of management consulting}

One type of consulting is the general model of management consulting developed by Milan Kubr in his book entitled Management consulting: A guide to the profession. Compared to the previous model, this model divides the counselling process into 5 phases including sub-steps. In the present model, the steps are not fixed, they depend on the specific counselling case. It is possible to omit or add phases, sub-phases, or to combine individual phases during the counselling process due to overlapping. It is also common to leap between phases.

A model very similar to that described by Kubr is described by Linda K. Stroh and Homer Johnson in The Basic Principles of Effective Consulting. The process presented in the book, which divides the counselling activity into 7 steps (Figure 3).

Figure 2: General model of management consulting

\begin{tabular}{|c|c|c|c|c|}
\hline $\begin{array}{l}\text { STARTING } \\
\text { POINT }\end{array}$ & DIAGNOSIS & PANNING & $\begin{array}{l}\text { IMPLEMEN- } \\
\text { TATION }\end{array}$ & $\begin{array}{l}\text { CLOSING } \\
\text { THE CASE }\end{array}$ \\
\hline $\begin{array}{l}\text { - Making } \\
\text { contact } \\
\text { - Preliminary } \\
\text { problem } \\
\text { identification } \\
\text { - Planning the } \\
\text { project }\end{array}$ & $\begin{array}{l}\text { - Objective } \\
\text { and problem } \\
\text { analysis } \\
\text { - Fact finding } \\
\text { - Synthesis }\end{array}$ & $\begin{array}{l}\text { - Developing } \\
\text { a solution } \\
\text { - Evaluation } \\
\text { - Recommen- } \\
\text { dations } \\
\text { - Implementa- } \\
\text { tion planning }\end{array}$ & $\begin{array}{l}\text { - Assisting } \\
\text { implementa- } \\
\text { tion } \\
\text { - Possible } \\
\text { modification } \\
\text { of proposals } \\
\text { - Training }\end{array}$ & $\begin{array}{l}\text { - Evaluation } \\
\text { - Report } \\
\text { - Follow-up }\end{array}$ \\
\hline
\end{tabular}

Figure 3: Model of Stroh and Johnson

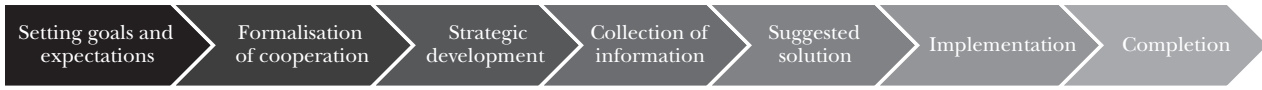

\section{Training and development model}

In consulting it is custom practice to organize development trainings when facing with issues that are of general nature, having at our disposal appropriate knowledge about it or even a ready-made process. Thus, during the training, we transfer to the client all the important knowledge that will enable it to solve the presented issue. Such trainings are expedient if they anticipate the client's given problems, hence acquired knowledge can prevent them to arise (Poór et al., 2018). 


\section{László Domokos: Assisting the Sustainability of a Well-managed State in Times...}

Figure 4: Training and development model

\section{Assessment}

Planning

Implementation

Evaluation

First, surveys should be conducted at the level of individuals or groups; strategies shall be analysed, interviews be held or even focus groups defined. After evaluating the survey, the problem or need, as well as the goal to be achieved are identified, as the second step in the process would be to design the adequate program. During planning, it is important to define the target audience and/or participants, the form of intervention, methods, structure, duration and costs. The third phase is about implementation, which covers the given training. It is followed by the evaluation as the last step, during which we assess the usefulness of the training and draw conclusions based on new interviews.

\section{Process management consulting model}

As a first phase, the program will be specified and any professional, methodological training will be provided for the client. The next phase is about identifying the problem based on systematic and analytical work. In the third phase, in addition to dealing with the problem, new solutions are identified, and the existing processes are optimized and developed. In the last phase, the developed program is initiated and implemented (Poór, 2010).

Figure 5: Process management consulting model

\section{Planning and preparation}

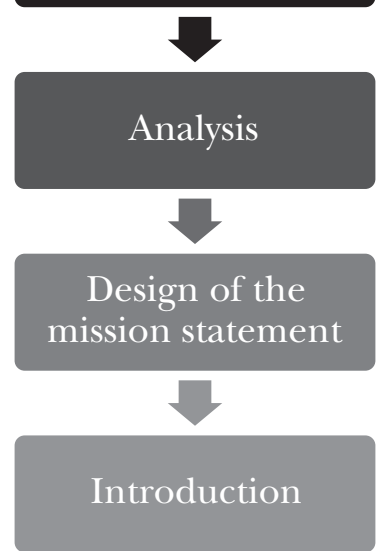


Civic Review · Vol. 16, Special Issue, 2020

\section{Organisational development model}

The process starts with an analysis: the external and internal factors that determine the organization must be assessed, then the internal processes of the organization must be analysed. Based on this, the problems can be pinpointed at a later stage. Once the problems have been identified, the specific objectives will be defined and a set of criteria will be developed, which will be able to evaluate and monitor the success of the implementation of the program at a later stage. One of the last steps is to work out the exact action plan, and the plan must be determined according to what processes we want to modify and exactly what methods we want to use to do so. Finally, it is time to implement the developed action plan and to evaluate the results based on the previously established system of criteria (Poór, 2010).

\section{Figure 6: Organisational development model}

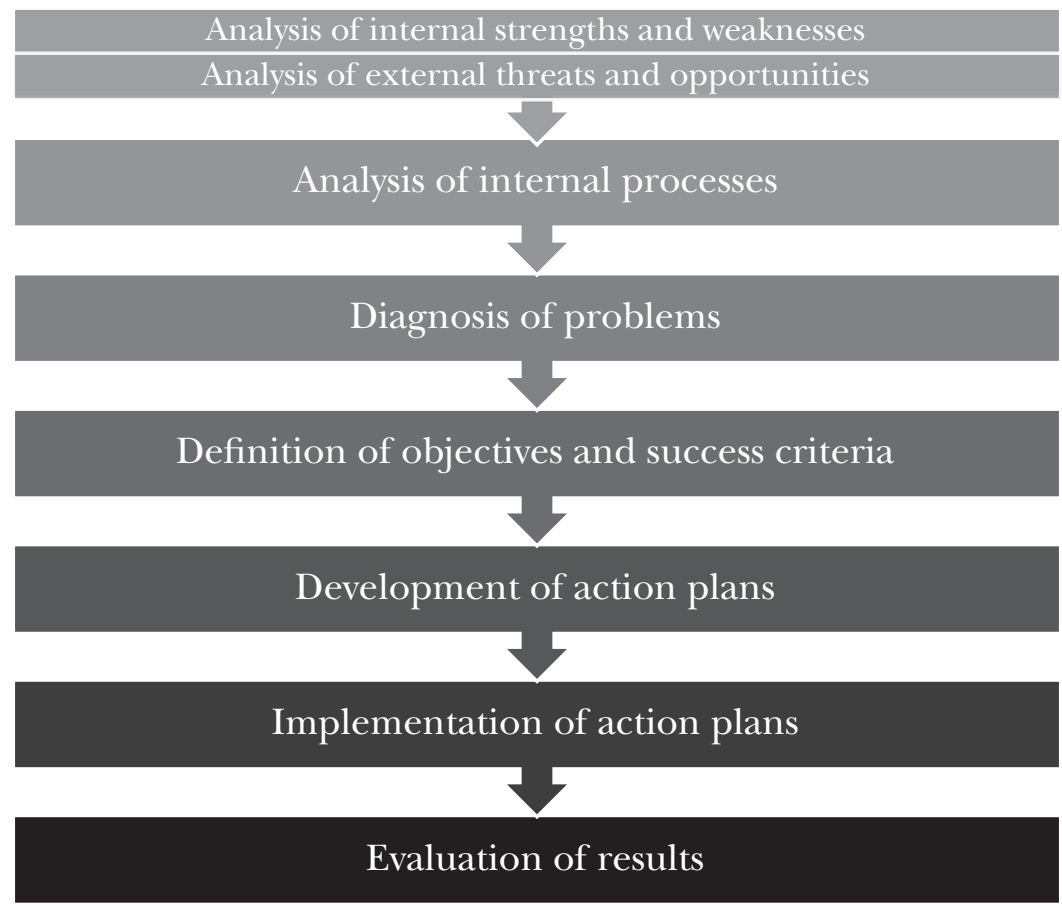

The SAO and the advisory activity

Each of the presented advisory models includes processes and/or steps that are also present in the advisory activity of the SAO. The initial concern of the SAO in connection with its activities is also to promote the efficient and effective use of public funds and public assets, and the first step to reach this goal is to insure the right functioning and responsible management of organizations. At present, this is not ensured 


\section{László Domokos: Assisting the Sustainability of a Well-managed State in Times...}

everywhere, the problems still exist, consequently risks and irregularities need to be identified. Previous audits and analysis all serve as references for assessing problem areas on which counselling can focus to become even more efficient. Using past experience, counselling can efficiently promote the development of forward-looking positive behaviours, without, of course, taking over responsibility from decision-makers, thus ensuring the subsequent objective audits with regard to these areas. Broadly speaking, the SAO's advice can also be seen as an activity that shall provide a kind of professional balance to unsubstantiated decision-making practices. As far as the performance of the control function of the $\mathrm{SAO}$ is concerned, it can be considered as part of the optimization process for good governance when the international requirements primarily INTOSAI, EU and UN recommendations in terms of appropriate domestic conditions are met (Domokos, 2019).

\section{ADVISORY ACTIVITy AS A VAlue ADDED FOR SOGIETY}

The advisory role is present at many levels in the daily activities of the supreme financial and economic audit institution, especially at the scientific level, which was confirmed by the Decision No. 35/2009 of the National Assembly, moreover, in the development of ethical leadership, which was supported by the Decision No. 34/2015 of the National Assembly. In addition to training and the journal of the SAO, the "good practice" seminar and a system of self-tests play an important role in counselling, which will be described in detail later in this article.

The SAO is present in the daily activities of the institutions not only with its audits, but also with its advisory activities. The self-tests developed by the SAO have been important advisory tools since $2014^{1}$, which are based on its audit experiences. This self-assessment tool developed for several target groups such as local governments, churches institutions, political parties, etc., which is continuously renewed in line with changes in the legislation, provides guidance to the organization performing the filling for continuous regular operation. ${ }^{2}$

The data concerning the download of self-tests in 2019 is shown in Figure 1. Interestingly, in the first quarter of 2020, self-test downloads increased exponentially, by about 66 percent compared to Q4 2019. During the state of emergency reporting period (March 2020), 900 downloads were made for self-tests, which shows that institutions have placed great emphasis on these self-training tools, which are exemplary in helping to improve public finances and respect the principles of responsible financial management. ${ }^{3}$

Although the role of self-tests is significant as statistics of downloads show an increasing number of fillings by each group of institutions, it should not be forgotten that self-testing is voluntary based making it necessary to introduce an advisory tool to encourage managers to act promptly.

Due to the pandemic the SAO attempted to support the work of one of the most burdened audited groups in 2020 by contacting them in separate letters in addition to offering them the opportunity to realise self-tests. The State Audit Office of Hungary 
Civic Review · Vol. 16, Special Issue, 2020

Figure 7: Downloading trends for self-tests by group of institutions (2015-2019)

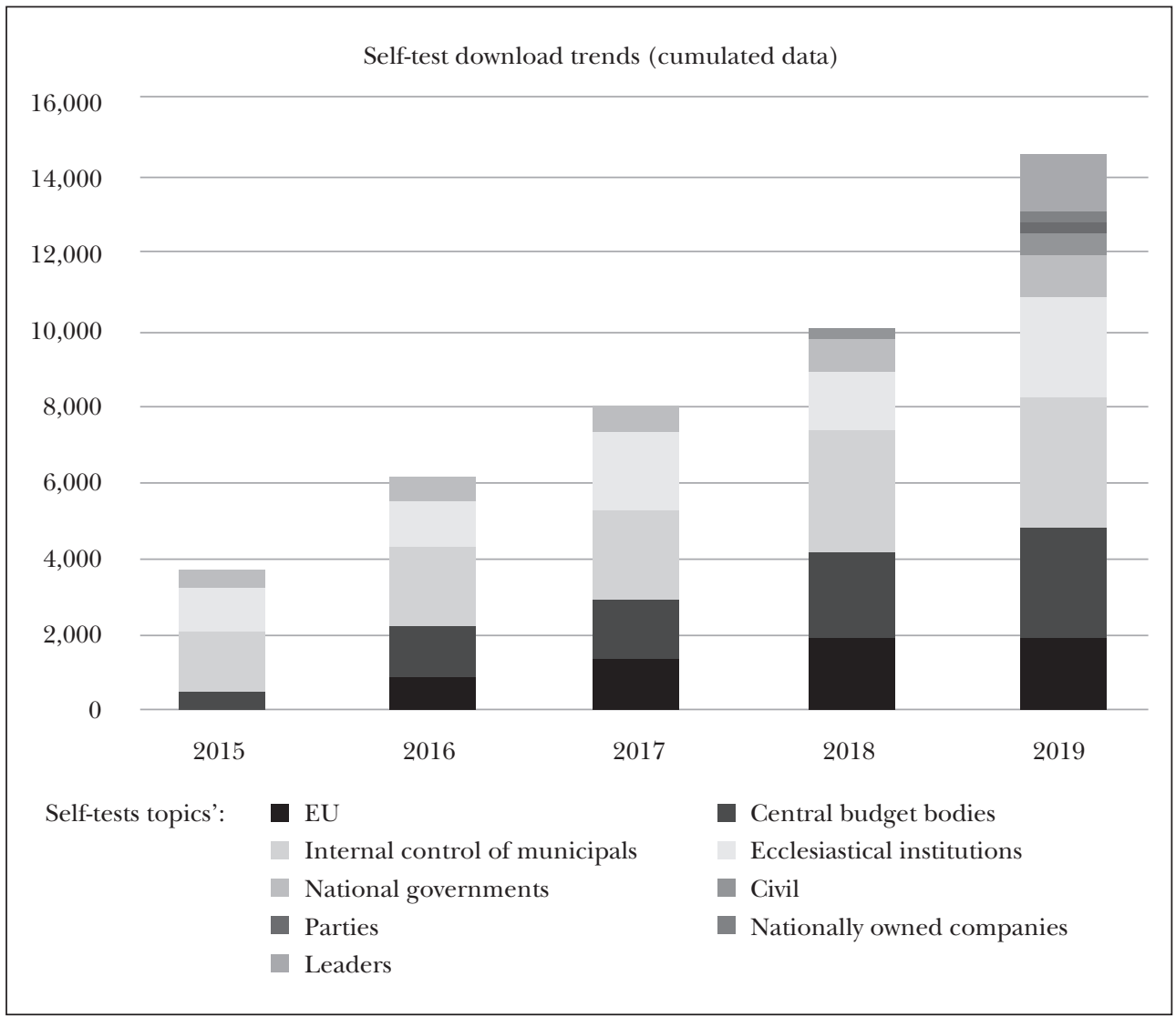

Source: State Audit Office of Hungary, 2020, p. 65

has performed the audit of central budgetary institutions entitled the Audit based on risk assessment of Central Budgetary Institutions (hospitals), the results of which were sent to hospital managers in supportive letters for raising their awareness given the pressure exerted on hospitals by the pandemic. In order for hospital managers to be able to focus all their attention on their responsibilities regarding health care, it was now more important than ever for hospitals to act quickly.

The State Audit Office considered it a priority to ensure that institutions operate and be managed transparently even in these difficult times, as according to the SAO's analysis, the state of emergency poses an increased risk of integrity or violations of rules, when the whole country need these "vital organisms" the most. ${ }^{4}$ It should not be forgotten that integrity at the organisation level can be an effective tool to prevent corruption (Pulay, 2017), so managing risks of integrity is essential.

The SAO issued letters to a total of 41 hospital managers, in which it drew the attention of the heads of the audited entities to the irregularities found and asked them 


\section{László Domokos: Assisting the Sustainability of a Well-managed State in Times...}

to assess the contents of the warning letters within 15 days and to take appropriate measures subject to notification of the President of the SAO. Among the detected irregularities, a representative infringement was that the value of the balance sheet items was not supported by an inventory pursuant to Sections 5 (1) and 22 (1) - (2) of the Government Decree No. 4/2013 (I. 11.) on Accounting of Public Finances (Áhsz.), and to Section 69 (1) of Act on Accounting, moreover, the records of the commitments did not comply with the requirements of Section 39 (3) and Paragraph II. 4. (h) of Annex 14. of the Áhsz., and an integrated risk management system has not been initiated.

But why is it important to flawlessly meet the requirements of these statutory elements? Articles dedicated to these issues were also published on the SAO News Portal presenting the risks in connection with the lack of documents and related social impact. A commitment is, for example, a duly executed legal declaration of a payment obligation which gives rise to a payment obligation against the appropriations of the budgetary institution. If the budgetary institution does not have records of the commitments or is inadequate:

"1. the budgetary institution does not know how much is at disposal of the expenditure appropriation for the remainder of the fiscal year; 2. does not know how much payment obligation he can make; 3 . is not aware of how (contrary to the provisions of Section 37 (1) of the Act on Public Finances) its payment obligations debit the amount of the expenditure appropriation; 4. (contrary to the provisions of Section 37 (1) of the Act on Public Finances) the power of financial countersigning prior to the commitment may not be exercised, regarding its content; 5 . the financial management of public funds may remain out of control and an unsecured payment obligation may arise, and finally; 6 . the principles of transparent and accountable management of public funds enshrined in the Fundamental Law may not be applied." ${ }^{5}$

This means that the organization does not have a record of commitments or does not have the reliable information to make its financial decisions as required by legal regulations, so it can make decisions that are unsubstantiated and for which it does not have financial coverage.

It is clear from the data of the self-tests however, that the public sector institutions also need and rely on the advisory tools of the SAO. At the same time, it is undeniable that the letters to the heads of the hospitals also purposefully supported their work.

\section{AnAlysis TO ASSIST SOCIAL UTILIZATION}

In addition to audits, the SAO is keen to put an increased emphasis on analysis within the scope of its advisory activities to contribute to the operation of a wellmanaged state. In its analysis, the SAO does not make findings, but sheds light on connections and effects, and draws attention to the dilemmas and risks that occur in the given field.

The SAO's analysis also focused on current topics in the crisis situation, thus helping to identify possible regulatory deficiencies and/or gaps, presenting current eco- 
Civic Review · Vol. 16, Special Issue, 2020

nomic trends, e.g. in the context of e-commerce or digital taxation, they assessed the social and/or demographic situation and/or risks, but also focused on measuring the performance of institutions, so that the definition of performance and its indicators was an important aspect during the epidemic, and they presented budget sustainability. These analysis are presented in this chapter.

Shopping patterns in Hungary are undergoing a transformation just like in the rest of the world, resulting in intensified online commerce exacerbated by the current epidemic situation. This is presented in the analysis entitled "The Aspects of the expansion of e-commerce in connection with public finances", which describes the effects and risks of the development and growth in volume of e-commerce, and draws attention to the fact that the renewal and modernization of the regulatory environment of e-commerce in the EU is badly needed. Closely related to the latter, another analysis entitled "Taxation of the Digital Economy" was prepared within the framework of the SAO's advisory activities in order to provide a comprehensive picture of the possibilities and difficulties of taxation of the digital economy to the stakeholders in the preparation of the relevant Hungarian legal regulations and to the public. The topic is becoming relevant indeed as digital economy and digital services sector are booming as a result of the coronavirus epidemic, making it more urgent to address tax regulatory issues. The analysis briefly presents the digital economy and the conceptual scope for its interpretation, as well as the possible variants of taxation of the digital economy in a comparative form, with a special focus on the audit activity required for the practical implementation of each variant.

In the current situation, it is particularly important to examine and test the financial vulnerability of the population, as the economic effects caused by the coronavirus epidemic can pose significant risks to households. The analysis entitled "Financial Vulnerability of the Population" published by the SAO in May 2020 reveals how the level of household indebtedness and vulnerability changed after the economic crisis of 2008, and what measures helped reducing vulnerability. Following the 2008 crisis, various measures were introduced by the Government and the Hungarian Central Bank (MNB) to reduce the vulnerability of household indebtedness, including: the creditworthiness test, a definition for the average loan fee indicator calculation, introduction of the income-related installment ratio, etc. In addition to these measures, raising the financial awareness of the population was also initiated, in which the SAO's Financial Awareness Project also plays a major role. As a result of the measures, significant changes took place, the net financial assets of households as a share of GDP increased, and the level of indebtedness decreased.

The analysis points out that despite the improvement, there are still more risks that need to be dealt with, especially for low-income households. Within new loans, the share of free-to-use personal loans is increasing, which entails a high repayment risk in the case of low-income households. The impact of the epidemic on the population is also a risk in the current situation, as a matter of fact declining incomes and job losses lead to repayment difficulties and increasing vulnerability. However, this can be mitigated through extraordinary measures taken by the government. 


\section{László Domokos: Assisting the Sustainability of a Well-managed State in Times...}

By virtue of its statutory task, the SAO gives its opinion on the central budget to the National Assembly, and also prepares several studies and analysis on the topic. The most recent of these is the "Budget Sustainability" analysis, which describes the evolution of central budget deficit-to-GDP ratios and public debt indicators, and thus their steady decline since 2011. This trend was broken in the first half of 2020 due to the coronavirus epidemic. The analysis identifies the value of public debt and the main risks affecting gross domestic product, and presents the factors used to reduce the identified risks. Being aware of the latter, plays a significant role in determining measures to curb the economic effects of the coronavirus epidemic.

The SAO regularly prepares analysis related to climate protection and environmental protection, to which special attention must now be paid, as in the current epidemiological situation these measures and/or goals are a bit neglected. However, measures to promote environmental protection are constantly present, as evidenced by the SAO's analysis entitled „Analysis of Green Procurement”, a topic in vogue as shown by the Act No. XLIV of 2020 on Climate Protection adopted by the National Assembly on June 3, 2020. The aim of the analysis is to support the implementation of strategic goals with regard to the climate change adopted by the National Assembly, as well as to present the domestic achievements and international experiences in one important area of climate and environmental protection the so-called green public procurement, as well as to explore the possibilities and relevance of developing green public procurements.

The State Audit Office of Hungary, by controlling the use of public funds and thereby contributing to the promotion of transparency and accountability, fulfils its legal obligations. In order to optimize the audit processes and reduce the time of their implementation, the use of key documents was initiated, and an analysis concerning the application of these was prepared by the SAO. The existence of these documents are important for the proper financial management and basic operational processes of organizations using public funds. The key documents are audit evidence that determines the structure, operation, responsibilities and financial management of the audited entity, certifies the regular operation of the organisation, in the absence of which the proper performance and management of the audited entity cannot be ensured and supported. Based on the examination of 29 audit reports of the Court of Auditors, the working document entitled "Detailed evaluation of cases arising from the lack of key documents" proposed to formulate the definition of the key document, regulate the exact order of its application and establish its ranking for even more efficient applicability.

A well-performing state cannot avoid measuring, continuously monitoring, evaluating and controlling the performance and effectiveness of the performance of public tasks. The SAO considers it a priority to support the creation and operation of systems that are fostering a culture geared to performance and results and the objective measurement and evaluation of public sector performance. The SAO's audits and analysis have in many cases affected the definition of the system of objectives and criteria for national and policy strategy-making, and the evaluation of the performance of the 
Civic Review · Vol. 16, Special Issue, 2020

public sector in recent years. Summarizing this experience, the analysis bearing the title "Measuring the Performance of the Public Sector" highlighted the key role of the systems of evaluation in strategy making and performance measurement, as well as the importance of setting precise objectives.

The effective, efficient and economical operation of health care systems that protect human health and safety have a prime role to play in a state of emergency caused by an epidemic. For this reason, in addition to the institutions performing public tasks, the central management bodies ${ }^{6}$ that manage, supervise and control the organizations concerned have an increased responsibility.

Taking into account the importance of the central government bodies, the SAO prepared its analysis on the basis of its audit experience, validating several points of view, which can contribute to the regular operation of the central government bodies and the more efficient and effective performance of their tasks.

The State Audit Office of Hungary is the supreme financial and economic audit organisation of the National Assembly, and as such, also supports the legislative work with its analysis. The SAO intends to provide a forecast and approach through its analysis entitled "Demographic risks, employment, pension system", based on credible information for shaping policies of the Hungarian Government regarding demography, employment and pension. Based on demographic and employment trends, the analysis explores the risks to the domestic employment situation and the pension system until 2060. On this basis, it presents 7 contexts that are paramount in the development of employment and pension policies. Among other things, measures related to increase healthy life expectancy and building the culture of self-support have been highlighted in the current epidemic situation.

The epidemic is a blatant illustration of the fact that various processes of change are taking place more and more often and faster these days that can be a real challenge not only for businesses but also for public finances. The current situation, the global epidemic, poses an even greater challenge to economic actors and public finances. For this reason, it is important to use appropriate change management as a tool to control changes. The current analysis of the SAO draws attention to the need to apply change management. Its main finding is that the application of change management is necessary within the framework of public finances because it is possible to continuously ensure economic growth through change management. It also points out that the conscious assuming of responsibility for the uncertainty inherent in the change ensures both adaptation to changes and contributes to planned thinking and financial management.

\section{A NEW TYPE OF CONTROL METHOD THAT SUPPORTS}

A WELL-MANAGED STATE

In addition to advices and analysis, there is, of course, a real need to strengthen transparency and integrity in the current situation, which we can achieve by carrying out audits, nevertheless, two important aspects must be borne in mind in an increasingly difficult economic and social situation: to cover the widest possible range of audits, as transpar- 


\section{László Domokos: Assisting the Sustainability of a Well-managed State in Times...}

ency is now the best way to strengthen trust, and to detect the operational and financial management risks of the auditees by putting the least possible burden on them.

The SAO created a new type of audit the so-called monitoring audit, which it first used based on the financial data of the Hungarian State Treasury. In 2020 the SAO has given a new aspect to the monitoring audits. Based on monitoring, the SAO gives evaluations but with a new method: requiring documents from the institution itself for the actual year. These types of audits present numerous benefits. On the one hand, the audit coverage can be significantly extended including previously unaudited segments, consequently the entire audited group will be scrutinized, on the other hand, it performs and evaluates targeted audits in a relatively small number and involving less required documents, but seeks to manage risks and irregularities and raising awareness of the efficient use of public funds and assets. This is an advantage not only for the SAO, but also for the audited entity, as it comes with less hassle due to the small number of documents, and also provides an opportunity to eliminate the risks and irregularities revealed under the monitoring type audit during an in-depth audit later.

The State Audit Office of Hungary run monitoring audits to test the integrity of local governments in 2020, thus helping to reduce the vulnerability of local governments. The timing of the topic is further strengthened by the fact that the protection against the virus and its negative social and economic effects also placed additional burdens on the shoulder of the local governments, and the maintenance of organizational integrity in the current situation requires more attention. It is indeed essential to establish and maintain an accountable regime for the performance of new tasks and a transparent internal regulation of extra resources that minimizes the potential for abuse and fraud. In this situation as well the State Audit Office of Hungary considers it its fundamental duty to be the guardian of public funds and to continue its audits among local governments, as the misuse of each tax forint deprives those most in need of support and makes it more difficult to perform the further necessary tasks.

To carry out the audits data was requested from 3197 local governments between March 20, 2020 and April 21, 2020. The results of the integrity survey conducted by the SAO between 2016-2018 showed that local governments are the most at risk groups among public representatives. Based on the findings of the survey, the local governments of smaller settlements are especially exposed to risks, as their control environment and integrity infrastructure are less structured. ${ }^{7}$

\section{SUMMARY}

Throughout the performance of its tasks during the coronavirus pandemic, the State Audit Office of Hungary has sought to reduce the negative social and economic impacts that require economic and social cohesion. This cooperation has become more important in the present situation emphasising on the advisory role and the launch of monitoring audits. The true demonstration of this cooperation at economic level is the activity of the SAO related to the budget, hence the continuous monitoring, persistent corrections and the ultimate accomplishment of know-how. 
The SAO considers sustainability to be a priority, which manifests itself in the life of the organization not only at the environmental but also at the social level, as one of the prioritized tasks of the SAO is to contribute to a well-managed state and strive for sustainability. In its undertakings it seeks to use a number of tools presented in this article, such as analysis addressing current issues: the vulnerability of the population, demographic challenges, digitisation, education, finance and, of course, climate protection goals related to sustainable growth. Another tool to support the goal of a well-managed state at national level, is the assisting audit work, which, in view of the virus epidemic, is mostly carried out through monitoring audits involving high coverage but lower workload from the auditees. The third major area that provides value added to society on the part of the $\mathrm{SAO}$ is counselling related measures listed in this article as warning letters and self-tests.

In summary, although the pandemic situation involves a lot of uncertainty, it has also created an environment that further raises awareness of the importance of change and/or crisis management, moreover, accelerates development of digitisation by creating a new work environment. It is important to be able to meet these challenges and provide auditing, analysis and advisory work that are supportive of the sustainability of a well-managed state.

\section{Notes}

1 "The self-test is a set of questions supporting the assessment and evaluation of the task performance and the regularity of internal control system of organisations operating by using public funds, which was prepared taking into account the given operational and regulatory environment and the specificity of the tasks, and it can be filled in by the stakeholders on a voluntary basis, for their own utilisation" (State Audit Office of Hungary, 2020, p. 65).

2 www.asz.hu/hu/sajtokozlemenyek/minden-alapitvany-tesztelheti-a-szabalyos-mukodeset.

3 www.aszhirportal.hu/hu/hirek/veszelyhelyzet-jelentosen-nott-az-asz-ontesztjeinek-letoltese.

4 www.asz.hu/hu/sajtokozlemenyek/tamogatja-az-asz-a-korhazparancsnokokat; www.aszhirportal.hu/hu/ hirek/asz-elorelepes-a-korhazak-gazdalkodasaban.

5 www.aszhirportal.hu/hu/hirek/gazdalkodasi-szabalyzat-es-a-kotelezettsegvallalasi-nyilvantartas.

6 The Act No. CXCV of 2011 (hereinafter referred to as the Áht.) provides for the possibility of restricting management powers, delegating scope of competence to another body or person in the case of a budgetary institution under the direction or supervision of the Government, and the delegation of the scope of competence to a budgetary authority other than the central managing authority under the management of the managing authority. The transfer of the scope of competence to a central management body may be based on a decision of the management body according to a specific Act or a Government Decree. In Hungary, central government bodies currently operate in the fields of health care, social affairs, child protection, public education, vocational training, water management, law enforcement and national defence, penitentiary management, and disaster management.

7 www.aszhirportal.hu/hu/hirek/asz-ellenorzesek-az-onkormanyzati-integritasert.

\section{REFERENGES}

Act No. C of 2000 on Accounting

Resolution No. 34/2015 of the National Assembly

Resolution No. 35/2009 of the National Assembly 


\section{László Domokos: Assisting the Sustainability of a Well-managed State in Times...}

4/2013. (I. 11.) Government Government Decree on public finance accounting

Act No. CXCV on Public Finance (Áht.)

Domokos, L. (2019): Ellenốrzés - a fenntartható jó kormányzás eszköze [Auditing - a tool for the sustainable good governance]. Akadémiai Kiadó, Budapest.

Felföldi, I. et al. (2020): Elemzés. Sarkalatos dokumentumok hiányából fakadó esetek részletezó kiértékelése [Analysis. Detailed evaluation of cases arising from the lack of key documents]. State Audit Office of Hungary, Budapest.

Ivey, A. and Simek-Downing, L. (1980): Counseling and Psychotherapy. Skills, Theories and Practice. PrenticeHall, Englewood Cliffs, N.J.

Jakubász, T. (2020): Jobban gazdálkodnak a kórházak [Better managed hospitals]. Interview with László Domokos, Magyar Nemzet, 18 July.

Kádár, K. et al. (2020a): Elemzés. A költségvetés fenntarthatósága [Analysis. The sustainability of the budget]. State Audit Office of Hungary, Budapest.

Kádár, K. et al. (2020b): Elemzés. A lakosság pénzügyi sérülékenységéról [Analysis. On the financial vulnerability of the population]. State Audit Office of Hungary.

Kádár, K. et al. (2020c): Elemzés. Az internetes kereskedelem bốvülésének közpénzügyi szempontjai [Analysis. Public financial aspects of the expansion of e-commerce]. State Audit Office of Hungary.

Kubr, M. (2005): Management Consulting. A Guide to the Profession. Fourth edition, Bookwell, New Delhi.

Lentner, Cs. and Cseh, B. (2020): Állami tulajdonban lévố közüzemi vállalatok múködésfenntartásának egyes gazdasági és jogszabályi kérdései vészhelyzet esetén [Some economic and legal issues of the operation of state-owned public utility companies in a state of emergency]. Gazdaság és Jog, Vol. 28, No. 5, 1-4.

Németh, E. et al. (2020): Elemzés. Demográfiai kockázatok, foglalkoztatás, nyugdíjrendszer [Analysis. Demographic risks, employment, pension system]. State Audit Office of Hungary, Budapest.

Németh, E. and Szikszainé Király, M. (2020): Elemzés. A közszféra teljesítménymérése - Nemzeti és Ágazati Stratégiák értékelése [Analysis. Public sector performance measurement evaluation of national and sectoral strategies]. State Audit Office of Hungary.

Pecze, M. (n. d.): Tanácsadási modellek c. elóadás anyaga, Konzultáció és szociális munka kurzus [The content of the lecture entitled. Consulting models, consultation and social work course]. WJLF SZM BA.

Poór, J. (2010): Menedzsment-tanácsadási kézikönyv [Management consulting handbook]. Akadémia Kiadó, Budapest, https://doi.org/10.1556/9789634540113.

Poór J. et al. (2018): Szervezeti képzések gyakorlata Magyarországon a nemzetközi adatok tükrében [The practice of organizational trainings in Hungary in the light of international data]. Vezetéstudomány, Vol. 49, No. 10-11, https://doi.org/10.14267/veztud.2018.10.03.

Pulay, Gy. (2017): Miért (lehet) eredményes eszköz a szervezeti integritás a korrupció megelôzésére? [Why (can) organizational integrity be an effective tool for preventing corruption?]. Köz-Gazdaság, Vol. 12, No. 4, 13-28.

Simon, J. (2020): Jelentés. Központi költségvetési szervek ellenôrzése - A központi költségvetési szervek (kórházak) kockázatértékelésen alapuló ellenôrzése [Report. Audit of central budget bodies. Risk-Based audit of central budget bodies (hospitals)]. State Audit Office of Hungary.

State Audit Office of Hungary (2020): Tájékoztató az Állami Számvevốszék 2019. évi szakmai tevékenységérôl és beszámoló az intézmény múködéséról az Országgyúlés részére [Summary report for the National Assembly on the professional activity and operation of the State Audit Office of Hungary in 2019]. State Audit Office of Hungary.

Stroh, L. and Johnson, H. (2006): The Basic Principles of Effective Consulting. L. Erlbaum Associates, Mahwah, https://doi.org/10.4324/9781410617453.

Szappanos, J. et al. (2020): Elemzés a zöld beszerzésekrôl [Analysis on the Green Procurements]. State Audit Office of Hungary, Budapest.

Teski, N. et al. (2020): Elemzés. A digitális gazdaság megadóztatásának aktuális kérdéseirôl, a modern gazdasághoz illeszkedô új uniós adószabályokról értékelô elemzés figyelemmel a terület ellenôrizhetôségére [Analysis. An evaluation analysis of current issues in the taxation of the digital economy, new EU tax rules in line with the modern economy, taking into account the ability to control it]. State Audit Office of Hungary. 